\title{
Clinical and laboratory findings in 503 cattle with traumatic reticuloperitonitis
}

\author{
Ueli Braun ${ }^{1 *}$ D, Sonja Warislohner ${ }^{1}$, Paul Torgerson², Karl Nuss ${ }^{1}$ and Christian Gerspach ${ }^{1}$
}

\begin{abstract}
Background: The study evaluated the results of clinical examination and haematological and serum biochemical analyses in 503 cattle with traumatic reticuloperitonitis (TRP).

Results: The most common clinical findings were abnormal demeanour and general condition (87\%), decreased rumen motility (72\%), poorly digested faeces (57\%), decreased rumen fill (49\%), fever (43\%) and tachycardia (26\%). In 58\% of the cattle, at least one of three tests for reticular foreign bodies (pinching of the withers, pressure on the xiphoid and percussion of the abdominal wall) was positive, and in $42 \%$ all three tests were negative. The most common haematological findings were decreased haematocrit in $45 \%$ of cattle and leukocytosis in $42 \%$. An increase in the concentration of fibrinogen in $69 \%$ of cattle and total protein in $64 \%$ were the main biochemical findings. The glutaraldehyde test time was decreased with coagulation occurring within 6 min in $75 \%$ of cattle.
\end{abstract}

Conclusions: In many cases, a diagnosis of TRP is not possible based on individual clinical or laboratory findings because even the most common abnormalities are not seen in all cattle with TRP.

Keywords: Cattle, Traumatic reticuloperitonitis, Foreign body tests, Haematological findings, Biochemical findings

\section{Background}

Traumatic reticuloperitonitis (TRP) remains one of the most important internal disorders of cattle in addition to abomasal displacement. One of the first large studies found that the incidence of TRP was as high as $80 \%$ [1], but more recent reports have shown that it is now approximately $2-12 \%$ [2-5]. Despite this decrease, the clinical implications remain the same. Traumatic reticuloperitonitis most commonly results from perforation of the reticulum by metal objects such as nails or wire that have been accidently incorporated into feed and ingested [6-9]. This may lead to localised peritonitis, sometimes involving neighbouring organs, and in severe cases it results in generalised peritonitis. Clinical signs of TRP have been described in a number of reference texts $[6,8,9]$. Acute disease usually results in distinct signs that include anorexia, decreased milk production, fever, ruminal atony and tympany, abdominal pain, arched back, abdominal guarding and tense abdomen $[6,8,9]$. The clinical signs in cattle with chronic disease on the other hand are often less

\footnotetext{
* Correspondence: ubraun@vetclinics.uzh.ch

'Department of Farm Animals, Vetsuisse-Faculty, University of Zurich,

Winterthurerstrasse 260, CH-8057 Zurich, Switzerland

Full list of author information is available at the end of the article
}

apparent. A short audible grunt is considered characteristic of acute TRP and may be a spontaneous response to reticular contractions or changes in posture such as lying down and getting up $[6,10,11]$. There may be additional signs in cattle with sequelae such as traumatic pericarditis [12], liver abscesses [13] or cranial functional stenosis [6, 9]. Cattle with acute localised peritonitis typically have neutrophilia with a regenerative left shift [9] and those with acute diffuse peritonitis have leukopenia with a degenerative left shift [9]. The most important biochemical findings are increased concentrations of total protein and fibrinogen. Tests for reticular foreign bodies may elicit a grunt, although other painful disorders of the thorax and abdomen may stimulate the same reaction $[6,10,14]$. Pinching of the withers, gradual application of pressure followed by sudden release of pressure on the area between the xiphoid and the umbilicus using a pole and percussion of the abdominal wall with a rubber hammer over the region of the reticulum are the most useful foreign body tests for TRP [15]. Others include the zone test developed by Kalchschmidt, leading the animal up and down a steep incline and ferroscopy to detect the presence of metal [15]. Pinching of the withers, abdominal percussion and the pole test have been the clinical tests used in more than 20,000 cattle over more 
than 30 years in our clinic. Other diagnostic tests include radiography and ultrasonography, which will be addressed in a separate paper. The clinical and laboratory findings in cattle with TRP have been thoroughly described in a number of standard texts. However, the majority of information is largely based on empirical evidence, and systematic evaluation of the clinical and laboratory findings in cattle with a definitive diagnosis of TRP has not yet been done. In particular, the frequency of positive responses to foreign body tests, which are considered an essential part of a diagnostic work-up in cattle with TRP, has not been determined. The goals of the present study were to describe the clinical and laboratory findings in 503 cattle with TRP, to establish the frequency of positive responses to foreign body tests and to determine which foreign body test elicited the most positive responses.

\section{Methods}

\section{Animals}

This was a retrospective study of 503 cattle that had a main diagnosis of TRP, which meant that the clinical signs were attributable to TRP and not another concomitant disease or disorder. The cattle were all greater than 1 year of age and had been admitted to the Veterinary Teaching Hospital, University of Zurich, from January 1, 2001 to December 31, 2014. The diagnosis of TRP was based on the results of ultrasonography, radiography, laparoruminotomy and/or postmortem examination. Cattle with TRP that had concomitant diseases causing anterior abdominal or caudal thoracic pain were excluded; this included 27 cows with bronchopneumonia and 24 cows with abomasal ulcers. All cattle that had been part of previous reports were not included in the present study. Traumatic reticuloperitonitis was diagnosed based on radiographic evidence of a foreign body that penetrated or perforated the reticular wall or was seen outside of the reticulum in 225 cattle and on ultrasonographic changes of the reticular wall in 403 cattle. Foreign bodies that penetrated or perforated the reticular wall were removed during laparoruminotomy in 196 cattle, and in 10 others, a reticular abscess was drained transcutaneously under ultrasonographic guidance. In all 61 cattle that were euthanased because of a poor prognosis, TRP was confirmed during postmortem examination. In all cattle, the diagnosis of TRP was based on more than one criterion. The results of ultrasonography, radiography, surgical treatment and postmortem examination as well as the outcome of treatment were described in a dissertation [16]. There were 496 females and 7 males, which ranged in age from 1.0 to 14.9 years (median, 4.1 years) with $97 \%$ of the cattle being more than 2 years of age. Breeds included Swiss Braunvieh (208), Holstein-Friesian (155), Simmental (124), Jersey (3), Eringer (1), Hinterwälder (1) and crossbred cattle (11). The length of illness ranged from 1 to 90 days (median, 4 days). The majority of cows $(n=168$, 33\%) had calved 0 to 8 weeks before becoming ill; this incidence was significantly higher than that of other reproductive stages $(P<0.01)$. There were no significant differences between the other reproductive stages. Of the 503 cattle, 58 had received no treatment before referral, 50 had been treated with an antibiotic, 88 had received a magnet and 209 had received an antibiotic and a magnet. A non-steroidal anti-inflammatory drug or metamizole was used in addition to other treatments in 183 cattle or exclusively in 11 cattle.

\section{Clinical examination}

The cattle underwent a thorough clinical examination [17]. The general health condition was evaluated by determining demeanour, appearance of hair coat and muzzle, skin elasticity, position of the eyes in relation to the sockets and skin surface temperature. Each animal was observed for signs of pain such as spontaneous grunting and bruxism. The general health condition was considered to be mildly to moderately abnormal when appetite and degree of alertness were decreased and severely abnormal when there was anorexia and apathy or constant bruxism or grunting. The rumen was assessed for degree of fill, number and intensity of contractions and layering of contents. Sensitivity in the reticular region was assessed by preventing the animal from breathing for a short period by placing a plastic rectal sleeve over the mouth and nose and listening for grunting during the following deep breath. This was followed by the foreign body tests, which included the pole test, pinching of the withers and percussion of the abdominal wall over the region of the reticulum with a rubber hammer. Each test was carried out four times, and the reaction of the animal was observed each time. A test was considered positive when it elicited a short grunt three out of four times. The response to a test was considered questionable when it elicited a grunt two out of four times and negative when the animal did not grunt or grunted only once. Swinging and percussion auscultation as well as a rectal examination were also carried out. Faeces were assessed for colour, consistency, amount, fibre particle length and abnormal contents.

\section{Urinalysis}

In 445 cattle, a urine sample was collected during spontaneous micturition, but in 33 cases catheterisation of the bladder was carried out. The colour and transparency of the urine were assessed macroscopically, and the specific gravity was determined using a refractometer (HRMT 18, A. Krüss Optronic GmbH, Hamburg, Germany). A urine test strip (Combur9 $9^{\circ}$, Roche, Basel) was used to determine urine $\mathrm{pH}$ and the presence of 
protein, erythrocytes, glucose, ketones, leukocytes, nitrite, urobilinogen and bilirubin.

\section{Rumen fluid analysis}

A sample of rumen fluid (200 to $300 \mathrm{ml}$ ) was collected using a Dirksen probe [15] and assessed for colour, odour, consistency and $\mathrm{pH}$. In addition, a methylene blue reduction time and the concentration of chloride were determined. The concentration of chloride in rumen fluid was carried out using an MK-II-Chloride Analyser 9265 (Sherwood, Cambridge).

\section{Haematological and serum biochemical analyses}

The following blood samples were collected from all cattle: $5 \mathrm{ml}$ of EDTA blood for haematological analysis, $10 \mathrm{ml}$ of whole blood for serum biochemistry, $2 \mathrm{ml}$ of whole blood mixed with $0.2 \mathrm{ml}$ heparin for venous blood gas analysis and $5 \mathrm{ml}$ of EDTA blood for the glutaraldehyde test. Haematological analysis included the determination of $\mathrm{PCV}$, total leukocyte count and the concentrations of fibrinogen and total protein using an automated blood analyzer (CELL-Dyn 3500, Abbott Diagnostics Division, Baar). A differential leukocyte count was done in cattle with leukopenia $(<5000$ leukocytes $/ \mu \mathrm{l}$ blood) or leukocytosis ( $>10,000$ leukocytes/ $\mu$ l blood). The concentrations of serum urea nitrogen and bilirubin and the activities of the enzymes aspartate aminotransferase (ASAT), $\gamma$-glutamyltransferase $(\gamma-G T)$ and glutamate dehydrogenase (GLDH) were determined at $37^{\circ} \mathrm{C}$ using an automated analyser (Cobas-Integra-800-Analyser, Roche Diagnostics, Basel) and the manufacturer's reagents (Roche-Reagents) according to the International Federation of Clinical Chemistry and Laboratory Medicine (IFCC). Venous blood gas analysis was done using an automated analyser (RapidLab 248, (Siemens Schweiz AG, Zurich). A glutaraldehyde test (Glutaltest, Graeub AG, Bern) was performed according to the manufacturer's instructions. Results were compared to reference intervals recently reported [18].

\section{Statistical analysis}

The program IBM SPSS Statistics 22.0 was used for analysis. Frequencies were determined for each clinical and laboratory variable. The Wilk-Shapiro test was used to test the data for normality. Means \pm standard deviations were calculated for normal data (rectal temperature, urine-pH, urine specific gravity, lymphocyte count, fibrinogen concentration and venous blood $\mathrm{pH}$ ) and medians for non-normal data (heart rate, respiratory rate, rumen $\mathrm{pH}$, rumen chloride concentration, haematocrit, white blood cell, neutrophil count, total protein, urea nitrogen and bilirubin concentrations, ASAT, $\gamma$-GT and GLDH activities, glutaraldehyde test time and $\mathrm{pCO}_{2}$, $\mathrm{HCO}_{3}^{-}$and base excess of venous blood). Differences in seasonal incidence of TRP and differences in occurrence at various reproductive stages were analysed using a oneway analysis of variance and the post hoc Bonferroni test. The 3-month periods of January to March, April to June, July to September and October to December, and the reproductive stages, which included the first 8 weeks postpartum, $>8$ weeks postpartum and open, and 3 months, 4 to 6 months and 7 to 9.5 months of gestation were compared. A value of $P<0.05$ was considered significant.

\section{Results}

Over the 14-year-study period, cattle with TRP constituted a yearly average of $7.1 \%$ (range, $5.1-9.1 \%$ ) of the bovine patients treated for internal disorders.

\section{Seasonality}

There were significantly more cattle $(n=232,46 \%)$ with TRP seen in the months of January to April than May to August $(n=146,29 \%)$ or September to December $(n=125$, 25\%) $(P<0.01)$ (Fig. 1).

\section{Clinical findings}

The general demeanour was normal in $65(13 \%)$ cattle, mildly to moderately abnormal in 425 (84\%) and markedly abnormal in $13(3 \%)$. The rectal temperature varied from 36.4 to $41.3^{\circ} \mathrm{C}\left(39.0 \pm 0.7{ }^{\circ} \mathrm{C}\right)$ (Table 1) and was mildly to severely increased $\left(39.1-41.3{ }^{\circ} \mathrm{C}\right)$ in 217 (43\%) cattle. The heart rate ranged from 40 to $162 \mathrm{bpm}$ (median, $76 \mathrm{bpm}$ ), and bradycardia was found in 24 (5\%) cattle and tachycardia in 130 (26\%). The respiratory rate was 12 to 100 breaths per minute (median, 28 breaths per min), and $102(21 \%)$ cattle had bradypnoea and $42(8 \%)$ had tachypnoea. The type of respiration was costoabdominal in $86 \%$ of cattle, costal in $1 \%$ and abdominal in $13 \%$.

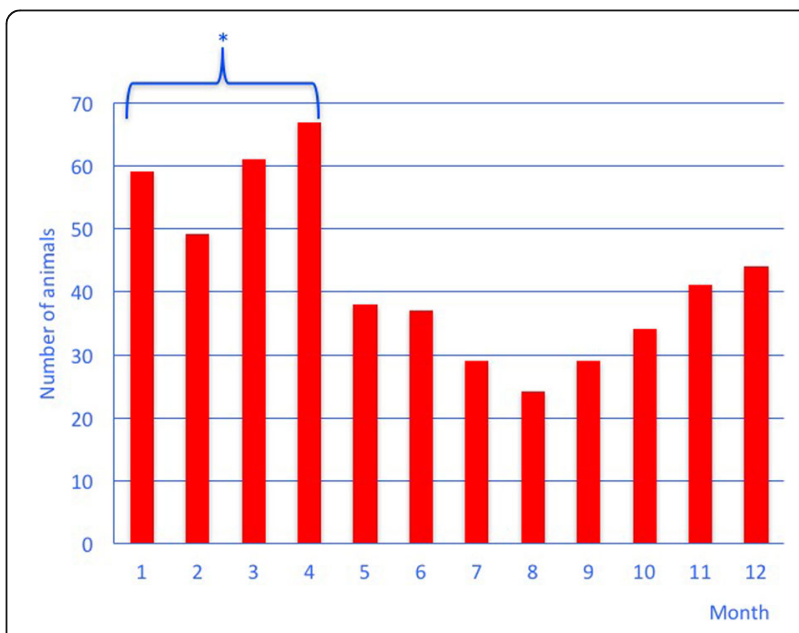

Fig. 1 Seasonal occurrence of traumatic reticuloperitonitis in cattle over a period of 14 years. ${ }^{*}$ Difference to May to August and to September to December $P<0.05$ 
Table 1 Rectal temperature and heart and respiratory rates in cattle with traumatic reticuloperitonitis

\begin{tabular}{lllll}
\hline Variable & Finding & Range & $\begin{array}{l}\text { Number } \\
\text { of cattle }\end{array}$ & Percent \\
\hline $\begin{array}{l}\text { Rectal temperature } \\
\left(39.0 \pm 0.7^{\circ} \mathrm{C}\right)\end{array}$ & Normal & $38.0-39.0$ & 263 & 52 \\
$(n=503)$ & Decreased & $36.4-37.9$ & 23 & 5 \\
& Mildly increased & $39.1-39.5$ & 146 & 29 \\
& $\begin{array}{l}\text { Moderately } \\
\text { increased }\end{array}$ & $39.6-40.0$ & 45 & 9 \\
& $\begin{array}{l}\text { Severely } \\
\text { increased }\end{array}$ & $40.1-41.3$ & 26 & 5 \\
& Normal & $60-80$ & 348 & 69 \\
$\begin{array}{l}\text { Heart rate } \\
\text { (median }=76 \text { bpm) } \\
(n=502)\end{array}$ & Decreased & $40-59$ & 24 & 5 \\
& Mildly increased & $81-100$ & 108 & 22 \\
& Moderately & $101-120$ & 15 & 3 \\
& increased & & & \\
& Severely & $121-162$ & 7 & 1 \\
& increased & & & \\
Respiratory rate & Normal & $21-40$ & 357 & 71 \\
per min $)(n=501)$ & Decreased & $12-20$ & 102 & 21 \\
& Increased & $41-100$ & 42 & 8 \\
\hline
\end{tabular}

Rumen fill was decreased in 242 (49\%) cattle, and in 70 (14\%) the rumen appeared fuller than normal (Table 2). Rumen motility was decreased in 354 (72\%) cattle, and the layering of rumen contents was abnormal or absent in 227 (45\%). Ruminal tympany was present in $51(10 \%)$ cattle in addition to other ruminal abnormalities.

Table 2 Results of rumen evaluation in cattle with traumatic reticuloperitonitis

\begin{tabular}{|c|c|c|c|}
\hline Variable & Finding & $\begin{array}{l}\text { Number } \\
\text { of cattle }\end{array}$ & Percent \\
\hline \multirow{3}{*}{$\begin{array}{l}\text { Rumen fill } \\
(n=495)\end{array}$} & Normal & 183 & 37 \\
\hline & Reduced & 242 & 49 \\
\hline & Fuller than normal & 70 & 14 \\
\hline \multirow{3}{*}{$\begin{array}{l}\text { Rumen motility } \\
(n=489)\end{array}$} & Normal & 135 & 28 \\
\hline & Reduced & 325 & 66 \\
\hline & Absent & 29 & 6 \\
\hline \multirow{4}{*}{$\begin{array}{l}\text { Ruminal contractions } \\
\text { per } 2 \text { min. } \\
(n=502)\end{array}$} & Normal (2-3) & 268 & 53 \\
\hline & None & 146 & 29 \\
\hline & 1 & 72 & 14 \\
\hline & 4 to 6 & 16 & 3 \\
\hline \multirow{5}{*}{$\begin{array}{l}\text { Stratification } \\
(n=499)\end{array}$} & Normal & 185 & 37 \\
\hline & Reduced & 195 & 39 \\
\hline & Absent & 32 & 6 \\
\hline & Tympanic & 51 & 10 \\
\hline & Firm content & 36 & 7 \\
\hline
\end{tabular}

Signs of pain occurred spontaneously in 179 (36\%) cattle and included arching of the back $(n=68)$, bruxism $(n=80)$ and grunting $(n=8)$. Twenty-three cattle had both arching of the back and bruxism. Walking on a lead rope elicited grunting in another five cattle. Bruxism was elicited in 43 (9\%) cattle, and at least one grunt, rarely more, was heard in 20 (4\%) after temporary interruption of breathing using a plastic rectal sleeve over the mouth and nose. Of the foreign body tests, a positive response was seen with the pole test in 210 (43\%), pinching of the withers in 191 (39\%) and pain percussion in $120(24 \%)$; this meant that the tests elicited grunting a minimum of three of the four times the test was done (Table 3). A positive response was seen with one of the three tests in 57 (19\%) cattle, with two of the tests in $52(17 \%)$ and with all three tests in 66 (22\%). Thus, a minimum of one of the tests was positive in 175 (58\%) cattle, and all three tests were negative in 129 (42\%).

Swinging and percussion auscultation on the left side of the animal was positive in $26(5 \%)$ cattle. The same test on the right side of the animal was positive in 87 (17\%) cattle.

Intestinal motility was decreased or absent in 252 (50\%) cattle. Faecal consistency was watery to loose in 121 (30\%), abnormally thick in 70 (14\%) and partly liquid and partly firm in 16 (3\%). The degree of comminution of faeces based on fibre particle length was abnormal in 286 (57\%), and the amount of faeces produced was decreased in 177 (35\%).

Rectal examination revealed distension of the rumen in $98(19 \%)$ cattle. The rumen felt firm in $51(10 \%)$ and tympanic in 25 (5\%) and was L-shaped in 15 (3\%). There was loss of negative pressure in 21 (4\%) cattle and crepitus in 8 .

\section{Urinalysis}

Urine $\mathrm{pH}$ was higher than normal in 203 (42\%) cattle, and the urine specific gravity was lower than normal in

Table 3 Results of foreign body tests in cattle with traumatic reticuloperitonitis

\begin{tabular}{llll}
\hline Test & Finding & Number of cattle & Percent \\
\hline Pole test & Positive & 210 & 43 \\
$(n=488)$ & Questionable & 72 & 15 \\
& Negative & 206 & 42 \\
Pinching of the withers & Positive & 191 & 39 \\
$(n=495)$ & Questionable & 80 & 16 \\
& Negative & 224 & 45 \\
Pain percussion & Positive & 120 & 24 \\
$(n=494)$ & Questionable & 91 & 19 \\
& Negative & 283 & 57 \\
\hline
\end{tabular}

Positive: at least three of four tests elicited a grunt Questionable: two of four tests elicited a grunt Negative: none or one of four tests elicited a grunt 
212 (46\%) (Table 4). Proteinuria was found in 57\% and haematuria in $72 \%$ of cattle; however, in most cases these abnormalities were mild and likely due to contamination. A few cattle had glucosuria (11\%) or ketonuria (9\%).

\section{Rumen fluid analysis}

The $\mathrm{pH}$ of rumen fluid was greater than 7.0 in 312 (72\%) cattle (Table 5). Based on the results of the methylene blue reduction test, rumen fluid was considered inactive in 236 (73\%) cattle. The concentration of chloride was decreased in 88 (20\%) cattle and increased in 113 (26\%) compared with the reference interval.

\section{Haematological and serum biochemical analyses}

The most common abnormalities in blood analysis were a decrease in haematocrit in 224 (45\%) cattle and leukocytosis in 209 (42\%) (Table 6). Neutrophilia occured in $90 \%$ of animals with leukocytosis and lymphopenia was noted in $36 \%$. The most common abnormalities in the biochemical profile were an increase in the concentration

Table 4 Results of urinalysis in cattle with traumatic reticuloperitonitis

\begin{tabular}{|c|c|c|c|}
\hline $\begin{array}{l}\text { Variable } \\
\text { Mean } \pm \text { sd }\end{array}$ & Finding & $\begin{array}{l}\text { Number } \\
\text { of cattle }\end{array}$ & Percent \\
\hline \multirow{2}{*}{$\begin{array}{l}\text { Transparency } \\
(n=474)\end{array}$} & Transparent & 463 & 98 \\
\hline & Opaque & 11 & 2 \\
\hline \multirow{3}{*}{$\begin{array}{l}\mathrm{pH}(n=478) \\
7.9 \pm 1.15\end{array}$} & Normal (7.0-8.0) & 203 & 42 \\
\hline & Decreased (5.0-6.9) & 73 & 16 \\
\hline & Increased (8.1-9.0) & 203 & 42 \\
\hline \multirow{3}{*}{$\begin{array}{l}\text { Specific gravity } \\
(n=461) \\
1020.6 \pm 11.18 \mathrm{~g} / \mathrm{l}\end{array}$} & Normal (1020-1040) & 229 & 50 \\
\hline & Decreased (1000-1019) & 212 & 46 \\
\hline & Increased (1021-1060) & 20 & 4 \\
\hline \multirow{3}{*}{$\begin{array}{l}\text { Protein concentration } \\
(n=478)\end{array}$} & Negative (< $30 \mathrm{mg} / \mathrm{dl})$ & 204 & 43 \\
\hline & + (approx. 30 mg/dl) & 251 & 53 \\
\hline & ++ (approx. 100 mg/dl) & 21 & 4 \\
\hline \multirow{4}{*}{$\begin{array}{l}\text { Erythrocytes } \\
(n=478)\end{array}$} & Negative & 348 & 73 \\
\hline & + (approx. 5-10) & 61 & 13 \\
\hline & ++ (approx. 25) & 29 & 6 \\
\hline & +++ (approx. 50) & 40 & 8 \\
\hline \multirow{4}{*}{$\begin{array}{l}\text { Glucose concentration } \\
(n=478)\end{array}$} & Negative $(<50 \mathrm{mg} / \mathrm{dl})$ & 425 & 89 \\
\hline & + (approx. 50 mg/dl) & 24 & 5 \\
\hline & ++ (approx. 100 mg/dl) & 18 & 4 \\
\hline & $+++(\geq 300 \mathrm{mg} / \mathrm{dl})$ & 12 & 2 \\
\hline \multirow{4}{*}{$\begin{array}{l}\text { Ketone bodies } \\
(n=477)\end{array}$} & Negative $(<10 \mathrm{mg} / \mathrm{dl})$ & 438 & 91 \\
\hline & + (approx. 10 mg/dl) & 19 & 4 \\
\hline & ++ (approx. 50 mg/dl) & 12 & 3 \\
\hline & $+++(\geq 150 \mathrm{mg} / \mathrm{dl})$ & 8 & 2 \\
\hline
\end{tabular}

+ Mildly increased

++ Moderately increased

+++ Severely increased
Table 5 Results of rumen fluid analysis in cattle with traumatic reticuloperitonitis

\begin{tabular}{llll}
\hline Variable & Finding & Number of cattle & Percent \\
\hline $\begin{array}{l}\mathrm{pH}(n=432) \\
\text { median }=8\end{array}$ & Normal (5.5-7.0) & 118 & 28 \\
$\begin{array}{l}\text { Methylene blue } \\
\text { reduction (min.) }\end{array}$ & $\begin{array}{l}\text { Hyperreactive } \\
(<3 \text { 3 Min.) }\end{array}$ & 19 & 72 \\
& $\begin{array}{l}\text { Moderately reactive } \\
\text { (3-6 Min.) }\end{array}$ & 68 & 6 \\
& $\begin{array}{l}\text { Inactive (> 6 Min.) } \\
\text { ( })\end{array}$ & 236 & 21 \\
$\begin{array}{ll}\text { Chloride concentration } \\
(n=435)\end{array}$ & Normal (15-25) & 234 & 73 \\
median $=20$ mmol/I & Decreased (6-14) & 88 & 54 \\
& Increased (26-99) & 113 & 20 \\
\hline
\end{tabular}

of fibrinogen in 345 (69\%) and total protein in 319 (64\%) cattle. The coagulation time in the glutaraldehyde test was less than 6 min in 371 (75\%) cattle. Venous blood pH was lower than normal in 170 (36\%) cattle and higher than normal in 88 (18\%) (Table 7).

\section{Discussion}

In 1954, a study of slaughter cattle found that the incidence of TRP was $80 \%$ [1], but when administration of magnets was introduced in the 1960s, the incidence decreased sharply [19]. The results of the present study showed that the yearly incidence of TRP as $7.1 \%$, which was in agreement with the results of other studies in which it ranged from 2 to $12 \%$ [2-5]. Traumatic reticuloperitonitis occurred more often in the months of December to April and there was a marked decrease in cases during the summer months, similar to the results of other studies [6,20], although one study found no association with time of year [21]. There is a lower risk of ingestion of a foreign body during the summer when cattle are grazing than in the winter when they are fed prepared feed. Traumatic reticuloperitonitis is extremely rare in cattle that are kept on pasture year-round [9] because they are more likely to detect foreign bodies in grass than in hay [22]. Contamination of feed with metal foreign bodies is greater with preparation and storage of hay than in fresh forage, although wire is no longer used to tie hay bales. In $33 \%$ of the cattle, TRP occurred in the first 2 months postpartum, which was the reproduction stage with the highest number of cases and in agreement with the results of another study (31.3\%) [23]. There were no differences among the stages of pregnancy, which was similar to the findings of one study [20] but contrasted the results of one other in which TRP was observed more often in the last trimester of pregnancy [6]. Differentiation of acute and chronic TRP was deliberately omitted for two reasons. Firstly, the definitions of acute and chronic TRP vary considerably depending on which author is cited, and secondly, reliable differentiation is not 
Table 6 Haematological and blood biochemical findings in cattle with traumatic reticuloperitonitis

\begin{tabular}{|c|c|c|c|}
\hline $\begin{array}{l}\text { Variable } \\
\text { (mean } \pm \text { sd or median) }\end{array}$ & Finding & $\begin{array}{l}\text { Number } \\
\text { of cattle }\end{array}$ & Percent \\
\hline \multirow{3}{*}{$\begin{array}{l}\text { Haematocrit (\%) } \\
(n=501) \\
\text { median }=30 \%\end{array}$} & Normal (30-35) & 218 & 43 \\
\hline & Decreased (18-29) & 224 & 45 \\
\hline & Increased (36-60) & 59 & 12 \\
\hline \multirow{3}{*}{$\begin{array}{l}\text { White blood cell count }(/ \mu \mathrm{l}) \\
(n=501) \\
\text { median }=9400 / \mu \mathrm{l}\end{array}$} & Normal $(5000-10,000)$ & 272 & 54 \\
\hline & Decreased (1500-4999) & 20 & 4 \\
\hline & Increased $(10,001-29,200)$ & 209 & 42 \\
\hline \multirow{3}{*}{$\begin{array}{l}\text { Neutrophil count }(/ \mu \mathrm{l}) \\
(n=211) \\
\text { median }=8568 / \mu \mathrm{l}\end{array}$} & Normal (1230-3350) & 17 & 8 \\
\hline & Decreased (380-1229) & 4 & 2 \\
\hline & Increased $(3351-26,280)$ & 190 & 90 \\
\hline \multirow{3}{*}{$\begin{array}{l}\text { Lymphocyte count }(/ \mu \mathrm{l}) \\
(n=222) \\
2576 \pm 1016 / \mu \mathrm{l}\end{array}$} & Normal (2190-5120) & 137 & 62 \\
\hline & Decreased(150-2189) & 81 & 36 \\
\hline & Increased (5121-7040) & 4 & 2 \\
\hline \multirow{3}{*}{$\begin{array}{l}\text { Fibrinogen concentration } \\
(n=499) \\
(8.6 \pm 3.1 \mathrm{~g} / \mathrm{l})\end{array}$} & Normal (4-7) & 131 & 26 \\
\hline & Decreased (2.0-3.9) & 23 & 5 \\
\hline & Increased (7.1-17.0) & 345 & 69 \\
\hline \multirow{3}{*}{$\begin{array}{l}\text { Total protein concentration } \\
(n=501) \\
(\text { median }=84 \mathrm{~g} / \mathrm{l})\end{array}$} & Normal (60-80) & 177 & 35 \\
\hline & Decreased (45-59) & 5 & 1 \\
\hline & Increased (81-122) & 319 & 64 \\
\hline \multirow{3}{*}{$\begin{array}{l}\text { Urea concentration } \\
(n=501) \\
(\text { median }=4.0 \mathrm{mmol} / \mathrm{l})\end{array}$} & Normal (2.4-6.5) & 373 & 74 \\
\hline & Decreased (0.7-2.3) & 58 & 12 \\
\hline & Increased (6.6-33.5) & 70 & 14 \\
\hline \multirow{2}{*}{$\begin{array}{l}\text { Bilirubin concentration } \\
(n=500) \\
(\text { Median }=4.6 \mu \mathrm{mol} / \mathrm{l})\end{array}$} & Normal $(\leq 6.5)$ & 359 & 72 \\
\hline & Increased (6.6-71.5) & 141 & 28 \\
\hline \multirow{2}{*}{$\begin{array}{l}\text { ASAT activity } \\
(n=501) \\
\text { (median }=69.0 \mathrm{U} / \mathrm{l})\end{array}$} & Normal $(\leq 103)$ & 425 & 85 \\
\hline & Increased (104-812) & 76 & 15 \\
\hline \multirow{2}{*}{$\begin{array}{l}\text { Y-GT activity } \\
(n=500) \\
(\text { median }=24.0 \mathrm{U} / \mathrm{l})\end{array}$} & Normal $(\leq 30)$ & 407 & 81 \\
\hline & Increased (31-154) & 93 & 19 \\
\hline \multirow{2}{*}{$\begin{array}{l}\text { GLDH activity } \\
(n=191) \\
\text { (median }=15.0 \mathrm{U} / \mathrm{l})\end{array}$} & Normal $(\leq 25.0)$ & 127 & 67 \\
\hline & Increased (25.1-522.0) & 64 & 33 \\
\hline \multirow{4}{*}{$\begin{array}{l}\text { Glutaraldehyde test } \\
(n=498) \\
\text { median }=3.5 \mathrm{~min} .\end{array}$} & Normal ( $\geq 10$ min.) & 91 & 18 \\
\hline & $6.1-9.9 \mathrm{~min}$. & 36 & 7 \\
\hline & $3.1-6.0 \mathrm{~min}$. & 128 & 26 \\
\hline & $\leq 3 \min$ & 243 & 49 \\
\hline
\end{tabular}

ASAT Aspartate aminotranferase, $\gamma$-GT $\gamma$-glutamyltransferase, $G L D H$ glutamate dehydrogenase

possible based on history and clinical examination alone. In our experience, cows with chronic TRP are often misdiagnosed as having acute TRP. Reliable differentiation of cattle with acute and chronic TRP can only be determined with a post-mortem examination, which was only carried out in 61 of 503 cattle.

The mean rectal temperature at the time of admission was $39.0 \pm 0.7{ }^{\circ} \mathrm{C}$, and only $29 \%$ of the cattle had a
Table 7 Venous blood gas analysis in cattle with traumatic reticuloperitonitis

\begin{tabular}{|c|c|c|c|}
\hline $\begin{array}{l}\text { Variable } \\
\text { (median; mean } \pm \text { sd) }\end{array}$ & Finding & $\begin{array}{l}\text { Number } \\
\text { of cattle }\end{array}$ & Percent \\
\hline \multirow{3}{*}{$\begin{array}{l}\mathrm{pH}(n=474) \\
7.42 \pm 0.05\end{array}$} & Normal (7.41-7.45) & 216 & 46 \\
\hline & Decreased (7.20-7.40) & 170 & 36 \\
\hline & Increased (7.46-7.58) & 88 & 18 \\
\hline \multirow{3}{*}{$\begin{array}{l}\mathrm{pCO}_{2}(n=472) \\
\text { (median }=43.3 \mathrm{mmHg})\end{array}$} & Normal (35-45) & 254 & 54 \\
\hline & Decreased (24.1-34.9) & 45 & 9 \\
\hline & Increased (45.1-75.6) & 173 & 37 \\
\hline \multirow{3}{*}{$\begin{array}{l}\mathrm{HCO}_{3}^{-}(n=474) \\
(\text { median }=26.5 \mathrm{mmol} / \mathrm{l})\end{array}$} & Normal (20.0-30.0) & 354 & 75 \\
\hline & Decreased (10.0-19.9) & 25 & 5 \\
\hline & Increased (30.1-58.9) & 95 & 20 \\
\hline \multirow{3}{*}{$\begin{array}{l}\text { Base excess }(n=464) \\
(\text { median = } 3.1 \mathrm{mmol} / \mathrm{l})\end{array}$} & Normal $(-2$ bis +2$)$ & 127 & 27 \\
\hline & Decreased $(-9.1$ bis -2.1$)$ & 65 & 14 \\
\hline & Increased (2.1 bis 28.8) & 272 & 59 \\
\hline
\end{tabular}

temperature between 39.1 and $39.5{ }^{\circ} \mathrm{C}$, which is considered typical of TRP. The majority of cattle (52\%) had a normal rectal temperature, which was likely attributable to having been ill for several days and treatment before admission to the clinic. In a clinical study of 1446 cattle with acute TRP, the mean rectal temperature was $39.5{ }^{\circ} \mathrm{C}$ [20], and in another study of cattle with TRP that had been ill for less than $24 \mathrm{~h}$, it was $39.3{ }^{\circ} \mathrm{C}$ [23]. A recently published reference text states that the rectal temperature is 39.5 to $40.0{ }^{\circ} \mathrm{C}$ in cattle with acute TRP and within the reference interval or mildly increased in cattle with chronic TRP [9]. A persistent mild increase in rectal temperature is characteristic of chronic inflammation [9].

The mean heart rate was $76 \mathrm{bpm}$, which was in the upper range of the reference interval and in agreement with the values reported in another study [23] and in a reference text, which states that the mean heart rate in cattle with acute localised TRP is $80 \mathrm{bpm}$ [9]. The mean heart rate in a clinical study of 1446 cattle with acute TRP was slightly higher at $82.4 \mathrm{bpm}$ [20]. A heart rate of more than $90 \mathrm{bpm}$ together with a rectal temperature of more than $40{ }^{\circ} \mathrm{C}$ indicates severe complications [9] such as generalised peritonitis or concurrent traumatic pericarditis.

The mean respiratory rate was 28 breaths per minute, which was in the upper range of the reference interval. Constable et al. [9] reported a mean respiratory rate of approximately 30 breaths per minute in cows with TRP. Cattle with TRP do not inhale as deeply as normal in an effort to mitigate pain elicited by movement of the fullyexpanded lungs and the diaphragm. An increase in respiratory rate is a compensatory mechanism, which sometimes is misdiagnosed as bronchopneumonia. In cattle with tachypnoea that do not respond to antibiotic therapy, a differential diagnosis should include TRP and other diseases. 
Rumen motility is often decreased or absent in cattle with TRP $[6,9]$. This was true in the majority $(72 \%)$ of cattle in the present study and is explained by inhibition of the gastric centre in the medulla oblongata via the vagal nerve because of pain associated with a foreign body [24]. However, decreased rumen motility is a nonspecific finding seen in many other diseases of the gastrointestinal tract as well as in systemic disorders. Ruminal tympany, due to decreased eructation because of pain, may be seen in cattle with TRP $[6,8,9]$ but occurred in only $51(10 \%)$ of our cases and was recognised as mild bulging of the left paralumbar fossa.

Cattle with TRP often have increased fibre particle length in the faeces $[6,11,25]$ because of dysfunction of the sorting mechanisms between the reticulum and omasum, which leads to the movement of incompletely digested feed into the omasum. An increase in fibre particle length occurred in the faeces of $60 \%$ of the cattle with TRP in the present study. Fibre particle length is an important indicator of disease of the reticulum, but an increase in length can also be due to dental disease or an increase in the speed of passage of ingesta through the gastrointestinal tract, such as occurs in diarrhoea [17].

Abdominal pain is a cardinal sign of TRP [6, 9-11, 14] and may manifest as arching of the back, grunting or bruxism, which may occur spontaneously or be elicited via foreign body tests. Arching of the back is a sign of parietal pain, and spontaneous grunting is a response to pain caused by reticular contractions. Bruxism is a sign of pain associated with many diseases and is uncommon in cattle with TRP [6]. Signs of pain were seen in 179 $(36 \%)$ of the cattle in the present study and the most common were bruxism $(n=80)$ and arching of the back $(n=68)$. Spontaneous grunting $(n=8)$ was uncommon; grunting may be difficult to hear, and thus auscultation of the larynx [6] or trachea [26] or placing the palm over the larynx to palpate vibrations [27] is recommended.

The pole test, pinching of the withers and pain percussion were considered by several authors to be the most important part of the clinical examination in cattle suspected of having TRP $[6,28-30]$. However, there are few studies that have investigated the response to foreign body testing and the presence of a foreign body in the reticulum $[23,31]$. In one study, grunting was elicited by pinching of the withers in $41 \%$ and deep palpation with a fist caudal to the sternum in $45 \%$ of cows [23], and in another, 16 (61\%) of 26 cows had at least one positive foreign body test [30]. In the present study, the pole test was most often positive (43\%) followed by pinching of the withers (39\%) and pain percussion of the reticular region (24\%); at least one test was positive in $58 \%$ of cattle, whereas all tests for foreign bodies were negative in $42 \%$ of cases. These are sobering results but one must remember that to elicit grunting in cattle with chronic TRP, considerable strength may be required when conducting foreign body tests [6] and in cows with chronic localised peritonitis, the grunt test may be positive, negative or equivocal [9]. Positive swinging and percussion auscultation on the left side was the result of concurrent left displacement of the abomasum in 13 cattle and ruminal atony in another 13 . On the right side, positive swinging and percussion auscultation was attributable to intestinal atony or diarrhoea in 82 , right displacement of the abomasum in three and caecal dilation in two. The loss of negative pressure in 21 cattle and crepitus in 8 were considered to be signs of peritonitis.

The leukogram and the plasma protein and fibrinogen concentrations are an aid in the diagnosis of TRP in cattle [8]. Acute cases are typically characterised by neutrophilia with a left shift and hyperfibrinogenaemia; however, the leukocyte count may vary in inflammatory disease from severely decreased to severely increased [32]. Leukocyte numbers vary with species and reflect the balance between production and release from the bone marrow and consumption [32]. In contrast to dogs, which have a rapid regenerative capacity and a relatively high bone marrow reserve of neutrophils, cattle have a slow regenerative capacity and a relatively low reserve. Thus dogs with chronic infection usually have persistent neutrophilia, whereas cattle may have normal neutrophil numbers and a normal differential cell count, or even neutropenia with a left shift because of a slow regenerative response. The majority of cattle (54\%) in the present study had normal leukocyte counts, which supports the findings of other studies [23, 33-35] in which neutrophilia was not a consistent feature of TRP. Forty-two percent of cattle had leukocytosis with greater than 10,000 leukocytes/ $\mu \mathrm{l}$ blood and $90 \%$ of these had neutrophilia. Acute localised peritonitis is commonly accompanied by neutrophilia [36, 37], often with a left shift $[13,38]$. Leukopenia was rare and only occurred in $4 \%$ of cattle in the present study. Leukopenia may occur after the first 1 or 2 days of severe acute inflammation because of migration of circulating neutrophils to the site of inflammation combined with reduced bone marrow response [39]. Stress-related endogenous corticosteroids also can suppress neutrophil numbers. Considering that more than half of a large sample of cows with TRP did not have neutrophilia makes determination of leukocyte numbers a poor diagnostic indicator. However, it is important to note that 272 cattle (54\%) had a total leukocyte count within the reference interval (5000-10,000 leukocytes/ $\mu \mathrm{l}$ blood) but did not have a differential leukocyte count done to minimise costs. It is not improbable that a left shift or lymphopenia may have been present in some of these animals. Erythropenia is a common sequel of chronic inflammation in cattle $[8,37$ and occurred in $4 \%$ of the cows in the present study. Chronic illness is the most common cause of mild and clinically insignificant anaemia 
and the multifactorial pathogenesis of this disorder has been described in detail [40]. Unlike leukocyte numbers, hyperfibrinogenaemia and hyperproteinaemia are good indicators of TRP in cattle and have been linked to this disorder in several studies [41-43]; in fact, in the present study the most important findings of blood analysis were increased fibrinogen concentrations in 69\% and increased protein concentrations in $64 \%$ of cattle with TRP. Fibrinogen is an acute-phase protein [44] and may be increased as early as 2 to 3 days after the onset of illness [8]. Fibrinogen is often increased in the absence of changes in leukocyte numbers and therefore is the better indicator for inflammation. A recent study on the diagnostic value of different acute-phase proteins concluded that the diagnostic accuracy of fibrinogen was significantly lower than that of serum amyloid A and haptoglobin [43], but other authors favour mainly haptoglobin and fibrinogen as biomarkers for TRP $[45,46]$ and consider serum amyloid A to be nonspecific [46]. High plasma protein concentrations primarily reflect high globulin concentrations and are typical of chronic TRP [41, 47]. However, increases in fibrinogen and plasma protein concentrations are not specific for TRP and the concentrations may be normal or decreased in cows with TRP as seen in this study. The glutaraldehyde clotting test is a point-of-care diagnostic test of considerable practical value used to detect increased gamma globulin and/or fibrinogen concentrations based on polymerisation of fibrinogen and gamma globulins with aldehyde resulting in clot formation of the test sample. The clotting time decreases proportionally with increases in fibrinogen and gamma globulin concentrations. There is a significant correlation between onset of coagulation of the test sample and fibrinogen and gamma globulin concentrations in the blood of cattle. Coagulation time was shorter than $6 \mathrm{~min}$ in $75 \%$ of tested cattle, and in $49 \%$ occurred within $3 \mathrm{~min}$; the respective positive predictive values of these test results for the diagnosis of an inflammatory process are 87.9 and $97.8 \%$ [48]. In the latter study, $62.9 \%$ of cattle with severe inflammatory changes had clotting times of less than $3 \mathrm{~min}$. However, this test is not specific for TRP and results of blood analysis including the glutaraldehyde test must be interpreted in view of the clinical picture. Reduced clotting time in the glutaraldehyde test, an arched back, fever, reduced rumen motility and positive foreign body tests allow a tentative diagnosis of TRP, but the absence of any of these findings does not rule out TRP. For this reason, the diagnosis should be confirmed by ultrasonographic and radiographic examination of the reticulum. A limitation of the study was that $3.6 \%$ of the 503 cattle had concomitant left or right displacement of the abomasum or caecal dilation, which may have affected laboratory findings. Such a low percentage likely had minimal effect on the average and mean values, but is certain to have affected the range of variation. The concomitant disorders would have led to an increase in the maximum values of haematocrit, concentration of urea nitrogen in serum, blood gas variables and concentration of rumen chloride.

\section{Conclusions}

Traumatic reticuloperitonitis cannot be diagnosed on the basis of individual clinical or laboratory criteria because even the most common abnormalities are not seen in all cattle with TRP. Furthermore, many of these findings are not specific for TRP and may occur in other disorders of the abdomen and thorax. A tentative diagnosis may be possible based on all the clinical and laboratory findings.

\section{Acknowledgements}

The authors thank the technicians of the Medical Laboratory for the haematological and biochemical analyses and the agricultural assistants for their help with the clinical examinations.

\section{Funding}

Not applicable since it was a retrospective analysis of medical records.

\section{Availability of data and materials}

The datasets used and analysed for this study are available from the corresponding author on reasonable request.

\section{Authors' contributions}

UB initiated, planned and supervised the study and prepared the manuscript, SW analysed the medical histories of the cows as part of her dissertation, PT was responsible for the statistics, KN and CG made substantial contributions to acquisition and interpretation of data and were involved in drafting and revising the manuscript. All authors read and approved the final manuscript.

\section{Ethics approval}

This study was not submitted for ethics committee review because it is a retrospective analysis of medical records of the Clinic of Ruminants, Vetsuisse Faculty, University of Zurich.

\section{Consent for publication}

All owners signed a consent form allowing us to use the animals and all the associated medical data for scientific analysis and publication.

\section{Competing interests}

The authors declare that they have no competing interests.

\section{Publisher's Note}

Springer Nature remains neutral with regard to jurisdictional claims in published maps and institutional affiliations.

\section{Author details}

${ }^{1}$ Department of Farm Animals, Vetsuisse-Faculty, University of Zurich, Winterthurerstrasse 260, CH-8057 Zurich, Switzerland. ${ }^{2}$ Section of Epidemiology, Vetsuisse-Faculty, University of Zurich, Winterthurerstrasse 260, $\mathrm{CH}-8057$ Zurich, Switzerland.

Received: 9 September 2017 Accepted: 27 February 2018

Published online: 05 March 2018

\section{References}

1. Maddy KT. Incidence of perforation of the bovine reticulum. J Am Vet Med Ass. 1954;124:113-5.

2. Poulsen JS. Prevention of traumatic indigestion in cattle. Vet Rec. 1976;98:149-51. 
3. Neumann N. Untersuchungen über das Vorkommen von Netzmagen-Fremdkörpern bei Schlachtrindern in Bayern, Dr Med Vet Thesis. Munich: University of Munich; 1979.

4. Starke A, Rehage J. Diagnose und Therapie bei abszedierender Reticuloperitonitis traumatica. Tierärztl Prax. 2000;28(G):93-5

5. Cramers T, Mikkelsen KB, Andersen P, Enevoldsen E, Jensen HE. New types of foreign bodies and the effect of magnets in traumatic reticulitis in cows. Vet Rec. 2005;157:287-9.

6. Dirksen G. Krankheiten von Haube und Pansen beim ruminanten Rind. In: Dirksen G, Gründer HD, Stöber M, editors. Innere Medizin und Chirurgie des Rindes. Berlin: Parey Buchverlag; 2002. p. 396-455.

7. Braun U, Milicevic A, Forster E, Irmer M, Reichle S, Previtali M, Gautschi A, Steininger K, Thoma R, Zeller S, Lazzarini A, Manzoni C, Ohlerth S. An unusual cause of traumatic reticulitis/reticuloperitonitis in a herd of Swiss dairy cows nearby an airport. Schweiz Arch Tierheilk. 2009;151:127-31.

8. Francoz D, Guard CL. Traumatic reticuloperitonitis (hardware disease, traumatic reticulitis). In: Smith BP, editor. Large Animal Internal Medicine. St. Louis: Elsevier Mosby; 2015. p. 805-7.

9. Constable PD, Hinchcliff KW, Done SH, Grünberg W. Diseases of the alimentary tract - ruminant. In: Veterinary medicine. A textbook of the diseases of cattle, horses, sheep, pigs and goats. St. Louis: Elsevier; 2017. p. 436-621.

10. Henniger RW, Mullowney PC. Anterior abdominal pain in cattle. Compend Contin Educ Pract Vet. 1984;6:453-63.

11. Garry F. Evaluating motility disorders of the bovine forestomach. Vet Med. 1990:85:634-42

12. Braun U. Traumatic pericarditis in cattle: clinical, radiographic and ultrasonographic findings. Vet J. 2009;182:176-86.

13. Braun U, Pusterla N, Wild K. Ultrasonographic findings in 11 cows with a hepatic abscess. Vet Rec. 1995:137:284-90.

14. Ward JL, Ducharme NG. Traumatic reticuloperitonitis in dairy cows. J Am Vet Med Assoc. 1994:204:874-7.

15. Dirksen G, Gründer HD, Stöber M. Verdauungsapparat. In: Dirksen G, Gründer HD, Stöber M, editors. Die klinische Untersuchung des Rindes. Berlin, Hamburg: Paul Parey; 1990. p. 288-400.

16. Warislohner S. Reticuloperitonitis traumatica beim Rind - eine Analyse von 503 Krankengeschichten, Dr Med Vet Thesis. Zurich: University of Zurich; 2017.

17. Rosenberger G. Clinical examination of cattle. Berlin, Hamburg: Paul Parey; 1990.

18. Braun U, Beckmann C, Gerspach C, Hässig M, Muggli E, Knubben-Schweizer G, Nuss K. Clinical findings and treatment in cattle with caecal dilatation. BMC Vet Res. 2012;8:75

19. Albright $J L$, Briggs $J$, Jessup RV. Long-term effects of magnets and management in the control of traumatic gastritis (hardware disease) in large commercial dairy herds. J Dairy Sci. 1962;45:547-9.

20. Leuenberger W, Martig J, Schneider E. Untersuchungen zur Diagnose und Therapie der Reticulitis traumatica des Rindes. 1. Teil. Schweiz Arch Tierheilk. 1978:120:213-29.

21. Gröhn YT, Bruss ML. Effect of diseases, production, and season on traumatic reticuloperitonitis and ruminal acidosis in cattle. J Dairy Sci. 1990;73:2355-63.

22. Schneider E. Zur Reticulitis traumatica: Was passiert mit dem krankmachenden Fremdkörper. Schweiz Arch Tierheilk. 1963;105:500-6.

23. Hjerpe CA. Studies on acute bovine traumatic reticuloperitonitis. II. Signs of traumatic reticuloperitonitis. J Am Vet Med Assoc. 1961;139:230-2.

24. Constable PD, Hoffsis GF, Rings DM. The reticulorumen: normal and abnormal motor function. Part I. Primary contraction cycle. Compend Contin Educ Pract Vet. 1990;12:1008-14.

25. Herzog K, Kaske M, Bischoff C, Kehler W, Hoeltershinken M, Starke A, Stöber M, Rehage J. Post surgical development of inflammatory adhesions and reticular function in cows suffering from traumatic reticuloperitonitis. Dtsch Tierärzt Wschr. 2004;111:57-62

26. Radostits OM. Detection and localization of abdominal pain. In: Radostis OM, Mayhew IG, Houston DM, editors. Veterinary clinical examination and diagnosis. London: WB Saunders; 2000. p. 444-5.

27. Stöber M. Beitrag zur Diagnose der Reticuloperitonitis traumatica des Rindes: die Betastung der Luftröhre als einfaches Hilfsmittel zur Feststellung des schmerzhaften Stöhnens bei den Fremdkörperproben. Dtsch Tierärztl Wschr. 1961;68:497-8.

28. Götze R. Die Fremdkörperoperation beim Rinde praxisreif durch extraperitoneale Pansennaht. Dtsch Tierärztl Wschr. 1934;42:353-7. 374-9.

29. Andres J. Zur modernen Diagnose, Prophylaxe und Therapie der Reticulitis traumatica des Rindes. Schweiz Arch Tierheilk. 1952;94:287-95.
30. Williams F. Einige diagnostische Hilfen zur Feststellung der traumatischen Retikuloperitonitis und Perikarditis beim Rind. Dtsch Tierärztl Wschr. 1974;81:558

31. Braun U, Götz M, Marmier O. Ultrasonographic findings in cows with traumatic reticuloperitonitis. Vet Rec. 1993;133:416-22.

32. Weiser $\mathrm{G}$. Interpretation of leukocyte responses in disease. In: Thrall MA, Weiser G, Allison RW, Campbell TW, editors. Veterinary hematology and clinical chemistry. Ames: Wiley-Blackwell; 2012. p. 127-39.

33. Brown JM, Kingrey BW, Rosenquist BD. The hematology of chronic bovine reticuloperitonitis. Am J Vet Res. 1959;20:255-64.

34. Smith DF, Becht JL, Whitlock RH. Traumatic reticuloperitonitis. In: Anderson NV, editor. Veterinary gastroenterology. Philadelphia/London: Lea and Febiger; 1992. p. 715-9.

35. Ramprabhu R, Dhanapalan P, Prathaban S. Comparative efficacy of diagnostic tests in the diagnosis of traumatic reticuloperitonitis and allied syndromes in cattle. Isr J Vet Med. 2003;58:68-72.

36. Tharwat M, Ahmed AF, El-Tookhy OS. Chronic peritonitis in buffaloes and cattle: clinical, hematological, ultrasonographic findings and treatment. J Anim Vet Adv. 2012;11:2775-81.

37. Reddy LSSVP, Reddy BS, Naik BR, Prasad CS. Haematological and clinical alterations with traumatic reticuloperitonitis in cattle. Int J Vet Sci. 2014:3:203-5.

38. Fecteau G. Management of peritonitis in cattle. Vet Clin North Am Food Anim Pract. 2005:21:155-71.

39. Tornquist SJ, Rigas S. Interpretation of ruminant leukocyte responses. In: Weiss DJ, Wardrop KJ, editors. Schalm's veterinary hematology. Ames: Wiley-Blackwell; 2010. p. 307-13.

40. Thrall MA. Nonregenerative anemia. In: Thrall MA, Weiser G, Allison RW, Campbell TW, editors. Veterinary hematology and clinical chemistry. Ames: Wiley-Blackwell; 2012. p. 81-6.

41. Dubensky RA, White ME. The sensitivity, specificity and predictive value of total plasma protein in the diagnosis of traumatic reticuloperitonitis. Can J Comp Med. 1983:47:241-4.

42. Jafarzadeh SR, Nowrouzian I, Khaki Z, Ghamsari SM, Adibhashemi F. The sensitivities and specificities of total plasma protein and plasma fibrinogen for the diagnosis of traumatic reticuloperitonitis in cattle. Prev Vet Med. 2004:65:1-7.

43. Nazifi S, Ansari-Lari M, Asadi-Fardqi J, Rezaei M. The use of receiver operating characteristic (ROC) analysis to assess the diagnostic value of serum amyloid a, haptoglobin and fibrinogen in traumatic reticuloperitonitis in cattle. Vet J. 2009;182:315-9.

44. Allison R. Laboratory evaluation of plasma and serum proteins. In: Thrall MA, Weiser G, Allison RW, Campbell TW, editors. Veterinary hematology and clinical chemistry. Ames: Wiley-Blackwell; 2012. p. 460-75.

45. Hirvonen J, Pyörälä S. Acute-phase response in dairy cows with surgically-treated abdominal disorders. Vet J. 1998:155:53-61.

46. Kirbas A, Ozkanlar Y, Aktas MS. Acute phase biomarkers for inflammatory response in dairy cows with traumatic reticuloperitonitis. Isr J Vet Med. 2015;70:23-9.

47. Gokce HI, Gokce G, Cihan M. Alterations in coagulation profiles and biochemical and haematological parameters in cattle with traumatic reticuloperitonitis. Vet Res Commun. 2007;31:529-37.

48. Doll K, Schillinger D, Klee W. Der Glutaraldehyd-Test beim Rind - seine Brauchbarkeit für Prognose und Diagnose innerer Entzündungen. Zbl Vetmed A. 1985:32:581-93.

\section{Submit your next manuscript to BioMed Central and we will help you at every step:}

- We accept pre-submission inquiries

- Our selector tool helps you to find the most relevant journal

- We provide round the clock customer support

- Convenient online submission

- Thorough peer review

- Inclusion in PubMed and all major indexing services

- Maximum visibility for your research

Submit your manuscript at www.biomedcentral.com/submit 